\title{
LOCALIZATION AND ACTIVITY OF LIPOXYGENASE IN Cd-TREATED SEEDLINGS OF PHASEOLUS COCCINEUS
}

\author{
EWA SKÓRZYŃSKA-POLIT ${ }^{1}$, BOŻENA PAWLIKOWSKA-PAWLĘGA ${ }^{2}$, \\ EWA SZCZUKA ${ }^{3}$, ANDRZEJ PLAK ${ }^{4}$, JERZY MELKE ${ }^{4}$ \\ ${ }^{1}$ Department of Plant Physiology \\ 2 Department of Comparative Anatomy and Anthropology \\ ${ }^{3}$ Department of Plant Anatomy and Cytology \\ ${ }^{4}$ Department of Soil Science \\ Maria Curie-Skłodowska University \\ Akademicka 19, 20-033 Lublin, Poland \\ e-mail: Ewa.Skorzynska@umcs.lublin.pl
}

(Received: June 16, 2004. Accepted: February: 22, 2005)

\begin{abstract}
Lipoxygenase was localized in the primary leaves of Phaseolus coccineus (L.), seedlings treated with $25 \mu \mathrm{M}$ $\mathrm{Cd}$ and in control plants using the immunogold method. The enzyme was localized mainly in the peripheral parts of protoplast of control plant cells. It was found in the cell wall, along the ER elements, at plastid lamellae and inside the mitochondria. In Cd-treated seedlings the elements of parenchyma cells showed an atypical inner structure. The immunolabelling of LOX was less intensive in comparison with control. The enzyme was found in the cytoplasm, at the cell wall area, vacuoles and in the plastid stroma as single gold particles. LOX activity optima were determined at $\mathrm{pH} 7.0$ and 8.0 for both linoleic and linolenic acid used as substrates. After 2 days of seedlings exposure to Cd the activity of LOX decreased at $\mathrm{pH} 7.0$ and 8.0 when linoleic acid was used as substrate, and strongly declined at $\mathrm{pH} 7.0$ after 4 days of the metal treatment. When linolenic acid was the substrate LOX activity slightly increased after 2 days of the plants exposure to $\mathrm{Cd}$, but after 4 days it rapidly decreased at $\mathrm{pH}$ 7.0. The changes in LOX activity are discussed.
\end{abstract}

KEY WORDS: Phaseolus coccineus, antibody, cadmium, lipoxygenase.

\section{INTRODUCTION}

Lipoxygenases (LOXs; EC 1.13.11.12) are a large family of enzymes which catalyze the dioxygenation of the long chain of fatty acids containing cis, cis-1,4-pentadiene structure to hydroperoxides (Maccarrone et al. 1994; Feussner and Wasternack 2002). Polyunsaturated long chain fatty acids as linoleic and $\alpha$-linolenic acid are ideal substrates for lipoxygenase (Siedow 1991), and further reactions of hydroperoxides are known as lipoxygenase pathway or octadecanoic pathway (Gardner 1995). LOX strongly prefers free fatty acids as substrates, but its activity with polyunsaturated fatty acids (PUFAs) estrified to phospholipids and with PUFAs estrified in neutral lipids such as triglycerides was also found (Feussner et al. 2001; Stelmach et al. 2001; see Feussner and Wasternack 2002).

Lipoxygenases occur in plants in various isoforms. They may differ in their properties, kinetic parameters or sub-

\footnotetext{
Abbreviations:

AA - ascorbate; AAS - atomic absorbtion spectroscopy; GSH - glutathione; LOX - lipoxygenase; PPFD - photosynthetic photon flux density
}

strate specificity (Fuller et al. 2001). Most plant lipoxygenase isoenzymes hydroperoxidize polyunsaturated fatty acids in a stereo-specific manner giving either 13(S)- or 9 (S)-hydroperoxides, and some yield a mixture of both (Gardner 1995).

Individual isoforms of LOX are found in different cellular compartments: the bulk of them in cytosol (Siedow 1991), some reports indicate the enzyme presence in chloroplasts (Bowsher et al. 1992), microsomal membranes (Todd et al. 1990) and bound with plasmalemma (Droillard et al. 1993; Vianello et al. 1995). In barley two lipoxygenases differing in their spatial and temporal expression appeared during barley grain development (Schmitt and Mechelen 1997).

Changes in LOX activity may be associated with losses of tertiary and secondary structures of protein. Conformational changes of soybean LOX1 were $\mathrm{pH}$-dependent $(\mathrm{Su}-$ dharshan et al. 2000). At pH 4.0 the enzyme lost its activity irreversible by dissociation of proteolytic domains. The lack of enzyme activity may be also caused by liberation of iron ions located in the active center of LOX. Such iron liberation occurred when polyunsaturated fatty acids relea- 
sed from membranes exceeded a certain threshold (Spiteller 2003).

LOX activity may be changed under abiotic and biotic stress (Hildebrand et al. 1988; Peever and Higgins 1989; Rickauer et al. 1990; Koch et al. 1992; Somashekaraiah et al. 1992; Melan et al. 1993). The mechanism of changes of LOX activity is still an open question. Likely the changes are caused both by a direct or indirect way. Being interested in the mechanism of $\mathrm{Cd}$ action on Phaseolus coccineus plants, we decided to localize LOX and estimate $\mathrm{pH}$ optima for LOX activity in the primary leaves of these plants. We were also interested in the occurrence of LOX isoforms in these plants and whether their distribution is changed during plant growth.

\section{MATERIALS AND METHODS}

\section{Plant material}

Runner bean plants (Phaseolus coccineus L., cv. Piękny Jaś) were germinated from seeds on wet filter paper in a thermostated darkened chamber $\left(23^{\circ} \mathrm{C}, 95 \%\right.$ relative humidity). From day $5^{\text {th }}$ the seedlings were cultivated hydroponically (four plants per pot) in aerated Knopp nutrient solution containing (in $\mathrm{mg}$ per liter): $\mathrm{Ca}\left(\mathrm{NO}_{3}\right)_{2} .4 \mathrm{H}_{2} \mathrm{O}-$ $1000 ; \mathrm{KH}_{2} \mathrm{PO}_{4}-280 ; \mathrm{MgSO}_{4} 7 \mathrm{H}_{2} \mathrm{O}-250 ; \mathrm{KCl}-120$; $\mathrm{H}_{3} \mathrm{BO}_{3}-10 ; \mathrm{MnSO}_{4}-25 ; \mathrm{CuSO}_{4}-2.5 ; \mathrm{ZnSO}_{4}$ - 5; $\left(\mathrm{NH}_{4}\right)_{6} \mathrm{Mo}_{7} \mathrm{O}_{24} \cdot 4 \mathrm{H}_{2} \mathrm{O}-1.25$. Iron was added in the form of ferric citrate $(1 \%, \mathrm{w} / \mathrm{v})-2.5 \mathrm{ml}$ per liter. The plants were grown at $21^{\circ} \mathrm{C}$ and PPFD of $140 \mu \mathrm{mol} \mathrm{m} \mathrm{m}^{-2} \mathrm{~s}^{-1}$ under a 16-h photoperiod. Cadmium at the final concentration of $25 \mu \mathrm{M}$ was added in the form of $\mathrm{CdSO}_{4}$ to the nutrient solution immediately after transferring the seedlings to the nutrient solution. After 2 and 4 days of plant exposure to $\mathrm{Cd}$ the primary leaves were analyzed and compared to their age-adequate controls.

Additionally, etiolated seedlings were taken for localization of LOX in their primary leaves.

\section{Immunocytochemistry}

For immunogold labelling, small segments (2-3 mm) from leaves of Phaseolus coccineus (L.) were fixed in 2\% paraformaldehyde and $1 \%$ glutaraldehyde dissolved in PBS (0.1 M phosphate buffer, $\mathrm{pH} 7.4,0.15 \mathrm{M} \mathrm{NaCl})$ for $24 \mathrm{~h}$ at $4^{\circ} \mathrm{C}$. Samples were rinsed several times in PBS and $0.5 \mathrm{M} \mathrm{NH}_{4} \mathrm{Cl}$ in PBS, dehydrated in ethanol, embedded in LR White resin (Sigma), and polymerised overnight at $60^{\circ} \mathrm{C}$. Thin sections were collected on nickel grids, treated with aqueous $0.56 \mathrm{M}$ sodium periodate for $30 \mathrm{~min}$, thoroughly washed with distilled water, and treated with 0.1 $\mathrm{M} \mathrm{HCl}$ for 10 min followed by $5 \mathrm{~min}$ water wash. The sections were incubated first in 1\% BSA in PBS for $30 \mathrm{~min}$ at room temperature, then with preimmune rabbit serum (Agrisera) diluted 1/1000 in PBS-BSA for $1 \mathrm{~h}$ at room temperature. After triplicate washing with PBS-BSA (each wash lasting $10 \mathrm{~min}$ ), the sections were incubated with PBS-BSA containing rabbit anti-LOX antiserum diluted $1 / 1000$ for $1 \mathrm{~h}$ and repeatedly washed with PBS-BSA. Goat anti-rabbit immunoglobulins conjugated to $10-\mathrm{nm}$ gold particles (GAR - gold) (Sigma) were diluted 1/50 in PBS$\mathrm{BSA}$ and then incubated for $40 \mathrm{~min}$ at room temperature. Then the sections were washed several times with PBS and redistilled water. As additional control samples were incu- bated with pre-immune serum and GAR-gold or with the latter only, omitting the primary antiserum. The sections were stained with $2 \%$ uranyl acetate for $5 \mathrm{~min}$ and Reynolds reagent (lead nitrate and sodium citrate) for $1 \mathrm{~min}$. All sections were examined with LEO 912 AB electron microscope.

\section{Extraction and determination of protein}

The plant material was deep frozen in liquid nitrogen and ground in $0.2 \mathrm{M}$ boric buffer $\mathrm{pH}$ 7.0. The homogenate was centrifuged at $15000 \times \mathrm{g}$ for $15 \mathrm{~min}$ and the supernatant was used for determination of protein concentration and LOX activity assay.

Protein concentration was determined according to the method of Bradford (1976), using the Bio-Rad protein assay (Munich, Germany) and BSA as standard.

\section{Estimation of LOX activity}

The activity of LOX (EC 1.13.11.12) was measured spectrophotometrically at $234 \mathrm{~nm}$ on Shimadzu UV160A spectrophotometer (Japan) with a thermostated CPS 240A chamber (Shimadzu, Japan). The reaction mixture contained citrate buffer in $\mathrm{pH}$ range from 5.0 to 6.0 or boric buffer in $\mathrm{pH}$ range from 7.0 to $11.0,25 \mu$ of the plant extract, and linoleic acid (18: 2) or $\alpha$-linolenic acid (18:3) as substrate in $3 \mathrm{ml}$ of the final volume. The reaction proceeded at $30^{\circ} \mathrm{C}$ for $4 \mathrm{~min}$. LOX activity was expressed as absorbance increase per $\mathrm{mg}$ of protein per minute.

\section{Preparation of the substrate}

Linoleic acid (18:2) as substrate was prepared as described earlier (Skórzyńska-Polit and Krupa 2003). The same procedure was applied when linolenic acid (18:3) was the substrate.

\section{Determination of cadmium content}

Cadmium accumulation in the primary leaves was measured using AAS-3300 (PerkinElmer) in samples mineralized in a mixture containing $\mathrm{HClO}_{4}: \mathrm{HNO}_{3}: \mathrm{H}_{2} \mathrm{O}$ (1.5:1.5:10 $\mathrm{v} / \mathrm{v})$.

\section{Statistical analysis}

The presented values are the means of the samples from three independent experiments, each at least in three replicates \pm SE. SigmaStat 3.0 software was used for calculations.

\section{RESULTS}

In etiolated 5-day-old seedlings of Phaseolus coccineus the parenchyma tissue of young primary leaves consisted of elongated cells surrounded by thin walls. Dense cytoplasm contained numerous plastids, mitochondria and small vacuoles (Fig. 1). In such parenchyma cells the immunogold method revealed subcellular localization of epiotopes binding LOX PAb. Positive immunoreaction to LOX was more intensive in the cytoplasm although the immunogold particles were observed also in the cell wall area (Fig. 2).

In the cytoplasm the immunogold particles were concentrated particularly around elongated ER elements (Fig. 3). Positive labelling was observed inside partially differentiated plastids (Fig. 4) and at the tonoplast (Fig. 5). The partic- 

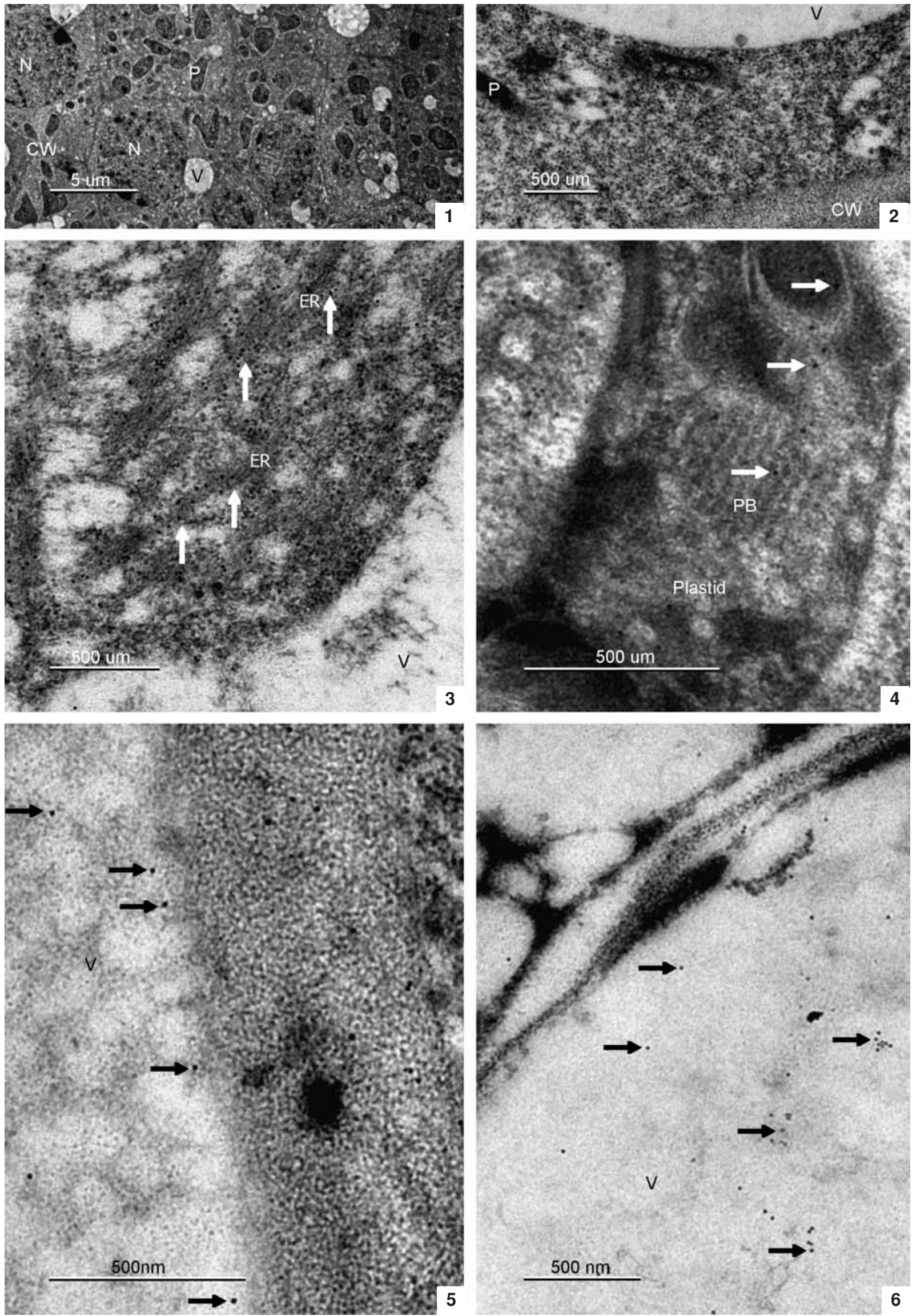

Figs 1-6. Immunogold LOX PAb localization in parenchyma cells of the primary leaves of etiolated seedlings of Phaseolus coccineus. EM.

Fig. 1. A low magnification micrograph of parenchyma cells of leaf. P - plastid; $\mathrm{CW}$ - cell wall; $\mathrm{N}$ - nucleus; $\mathrm{V}$ - vacuole. Fig. 2. A high magnification micrograph in a portion of parenchyma cells. Note immunogold particles in the cytoplasm and in the cell wall area. $\mathrm{P}$ - plastid; CW - cell wall; V - vacuole. Fig. 3. Immunogold particles in the cytoplasm are particularly concentrated at ER elements. Note an occurrence of dense cytoplasm in the etiolated cell. ER - endoplasmatic reticulum; V - vacuole. Fig. 4. Immunogold particles inside the plastid. PB - prolamellar body. Fig. 5. Immunogold particles are particularly concentrated at the tonoplast. V - vacuole. Fig. 6. A portion of vacuole with imunogold particles. 

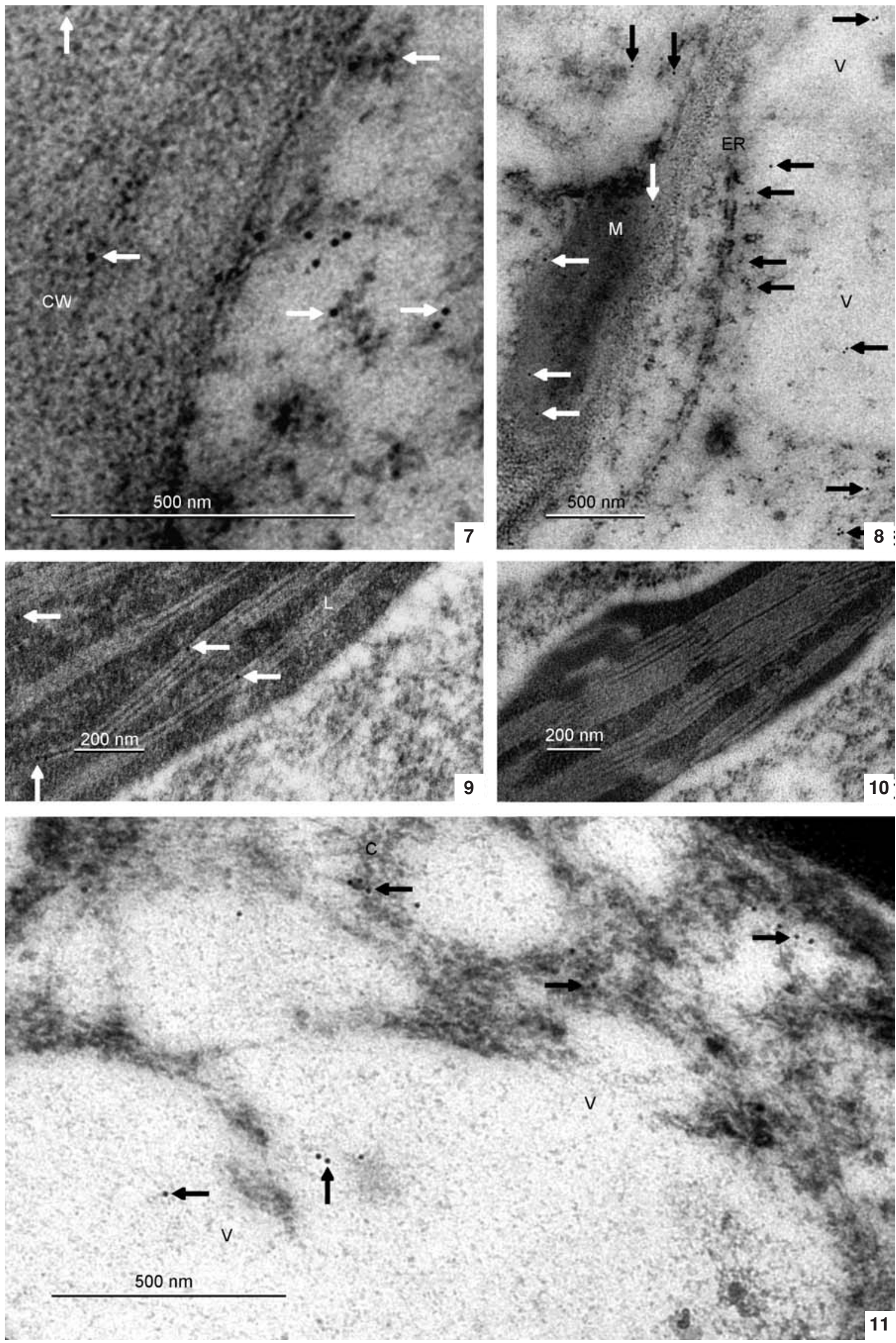

Figs 7-11. Immunolabelling to LOX in parenchyma cells of the primary leaves of 7-day-old Phaseolus coccineus seedlings (growing 2 days in the nutrient solution). EM.

Fig. 7. Portion of the peripheral cytoplasm of the parenchyma cell with immunogold particles. Note the presence of single particles in the cell wall area. $\mathrm{CW}$ - cell wall. Fig. 8. Portion of the cytoplasm with immunogold particles concentrated around the ER elements (arrows) and inside the mitochondrion (M). Fig. 9. A part of plastid with undifferentiated lamellae (L) into grana and stroma. The immunogold particles are localized apparently at the lamellae. Fig. 10. The control reaction with pre-immune serum showed negative immunogld result in the plastid. Fig. 11. Portion of the cytoplasm and vacuoles with single immunogold particles. 

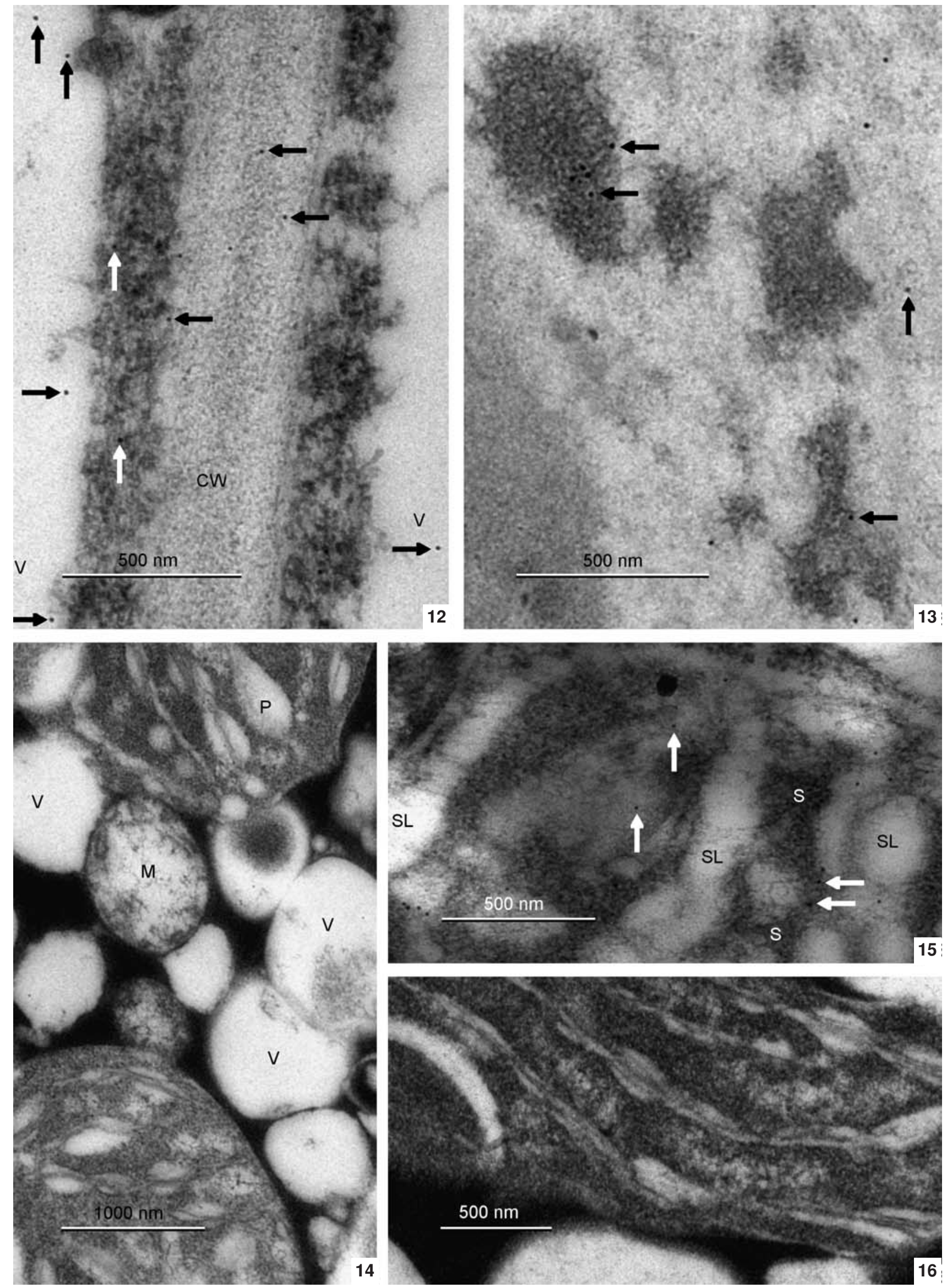

Figs 12-16. Immunolabelling to LOX in parenchyma cells of the primary leaves of Phaseolus coccineus treated with 25 uM Cd for 2 days. EM.

Fig. 12. Immunogold particles concentrated mainly in the peripheral cytoplasm. Single particles in vacuoles (V) and in the cell wall (CW) area. Fig. 13. Portion of the vacuole with immunogold particles concentrated in its dense contents (arrows). Fig. 14. Portion of the cytoplasm with atypical plastids (P), mitochondria (M) and numerous vacuoles (V). Fig. 15. Portion of the plastid with swollen lamellae (SL) and immunogold particles in the stroma (S). Fig. 16. The control reaction with pre-immune serum showed negative immunogld result in the plastid. 
les were situated rather uniformly in the vacuoles, but sometimes several of them formed small aggregates (Fig. 6).

Immunolabelling to LOX in parenchyma cells of the primary leaves of 7-day-old control young seedlings growing 2 days in the nutrient solution showed resemblance to LOX localization in etiolated seedlings. The single immunogold particles were randomly localized in the cytoplasm, but they also formed aggregates concentrated mainly in the peripheral parts of the protoplast. Single particles were rarely observed in the cell wall (Fig. 7). Small groups of the immunogold particles were found along the ER elements and single particles inside the mitochondria (Fig. 8) and vacuoles (Fig. 11). In cells of control primary leaves the immunolabelling to LOX was observed inside the plastids with lamellae undifferentiated into grana and stroma. In this case, the single immunogold particles were situated at the lamellae (Fig. 9). In control micrograph of the plastid any gold particles were not found. This section was incubated with preserum and GAR-gold, omitting the primary antibody (Fig. 10).

The immunolabelling to LOX in the primary leaves of Cd-treated runner bean plants was less intensive in comparison to control and etiolated seedlings. The immunogold particles were found in the cytoplasm, the cell wall area and in the vacuoles (Fig. 12). In most cases the single particles were randomly distributed inside the vacuoles, but sometimes they formed groups consisting of several particles. These groups were situated in the condensed content of vacuoles (Fig. 13). The elements of parenchyma cells of the primary leaves in Cd-treated seedlings show an atypical inner structure. In electron dense cytoplasm numerous small vacuoles, mitochondria without a typical inner structure and plastids with vesicles and swollen lamellae were found (Fig. 14). In such partially changed cells the immunolabelling was positive only in the plastids. The immunogold particles were grouped in the plastid stroma (Fig. 15). In control micrograph of the plastid section incubated with pre-immune serum and GAR-gold, omitting the primary antibody there was no found any gold particles (Fig. 16).

To find the $\mathrm{pH}$ optimum for LOX activity in the primary leaves of Phaseolus coccineus plants, $\mathrm{pH}$ range from 5.0 to 10.0 was applied. The highest LOX activity was found at pH 7.0 and 8.0, both for linoleic acid (18:2) and linolenic acid (18:3), therefore, these $\mathrm{pH}$ values were optima for the enzyme activity occurring in the plants (Fig. 17). In 7-day-old plants of Phaseolus coccineus LOX activity measured at $\mathrm{pH} 7.0$ and $\mathrm{pH} 8.0$ was almost the same for both linoleic and linolenic acid which were used as substrates (Fig. 17A).

After 4 days of growth of control plants in the nutrient solution LOX activity was the highest at $\mathrm{pH} 7.0$ with linolenic acid as substrate (Fig. 17B). At pH 8.0 activity of this enzyme was lower than at $\mathrm{pH} 7.0$ for both substrates.

When linoleic acid was used as substrate LOX activity in the primary leaves in Cd-treated plants decreased to $92 \%$ and $78 \%$ of control at $\mathrm{pH} 7.0$ and 8.0, respectively (Fig. 18A). After 4 days of plant exposure to Cd LOX activity at $\mathrm{pH} 7.0$ decreased to $47 \%$ of control and at $\mathrm{pH} 8.0$ it was slightly higher than in control (118\% of control) (Fig. 18B). Conversely, when linolenic acid was added to the incubation mixture LOX activity increased to $134 \%$ and $131 \%$ of control at $\mathrm{pH} 7.0$ and 8.0 respectively in plants treated with $\mathrm{Cd}$ for 2 days (Fig. 19A), but after 4 days of
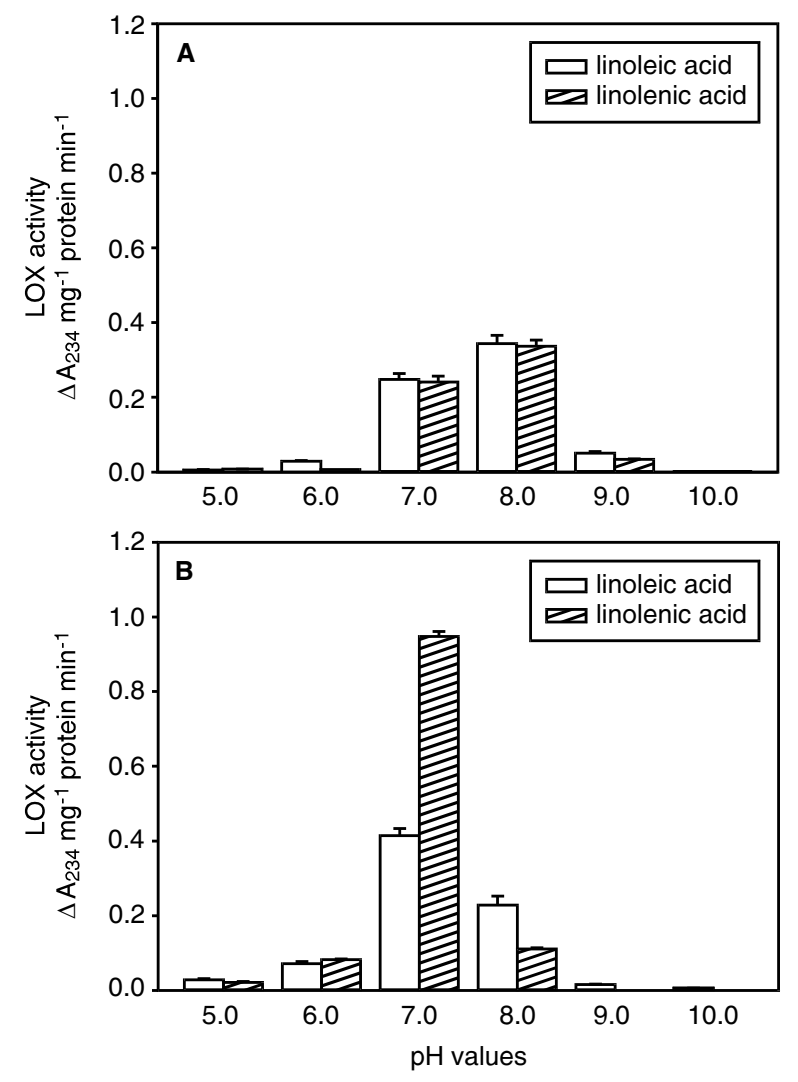

Fig. 17. Determination of $\mathrm{pH}$ optima for LOX activity in crude extract from the primary leaves of control seedlings growing in the nutrient medium for 2 (A) and 4 (B) days with usage of linoleic acid or linolenic acid as substrate.

their exposure to the metal LOX activity decreased to $66 \%$ and $87 \%$ of control at $\mathrm{pH} 7.0$ and 8.0, respectively (Fig. 19B).

The accumulation of Cd was $11.61 \pm 0.82 \mu \mathrm{g} \mathrm{g}^{-1} \mathrm{DW}$ and $14.96 \pm 1.18 \mu \mathrm{g} \mathrm{g}^{-1} \mathrm{DW}$ after 2 and 4 days of seedlings exposure to the metal, respectively.

\section{DISCUSSION}

According to literature data a high activity of LOX is related to the early stages of plant growth (Vick and Zimmerman 1976; Peterman and Siedow 1985; Matsui et al. 1988; Kato et al. 1991; Kato et al. 1992; Melan et al 1994; Schmitt and Mechelen 1997). In 20-day-old seedlings of Arabidopsis thaliana LOX activity was much higher than in 8-week-old plants (Skórzyńska-Polit and Krupa 2003). Genetical evidences have been given about the expression of LOX during germination and at the early growth stages of plants (Melan et al. 1994; Holtman et al. 1996). This enzyme was shown to be randomly distributed throughout the cytoplasm in cells of germinating soybean seeds (VernooyGerritsen et al. 1984). Five-day-old etiolated seedlings and 7-day-old seedlings of Phaseolus coccineus (growing for 2 days in the nutrient solution) were taken to localize LOX in their primary leaves. In growing etiolated primary leaves of runner bean plants LOX was found mainly in the cytoplasm around the endoplasmic reticulum (ER) elements (Figs 1-6). It is not surprising since ER plays an important role in the synthesis of lipids and proteins which are destined to be inserted in the cell membrane. Smooth ER is the 

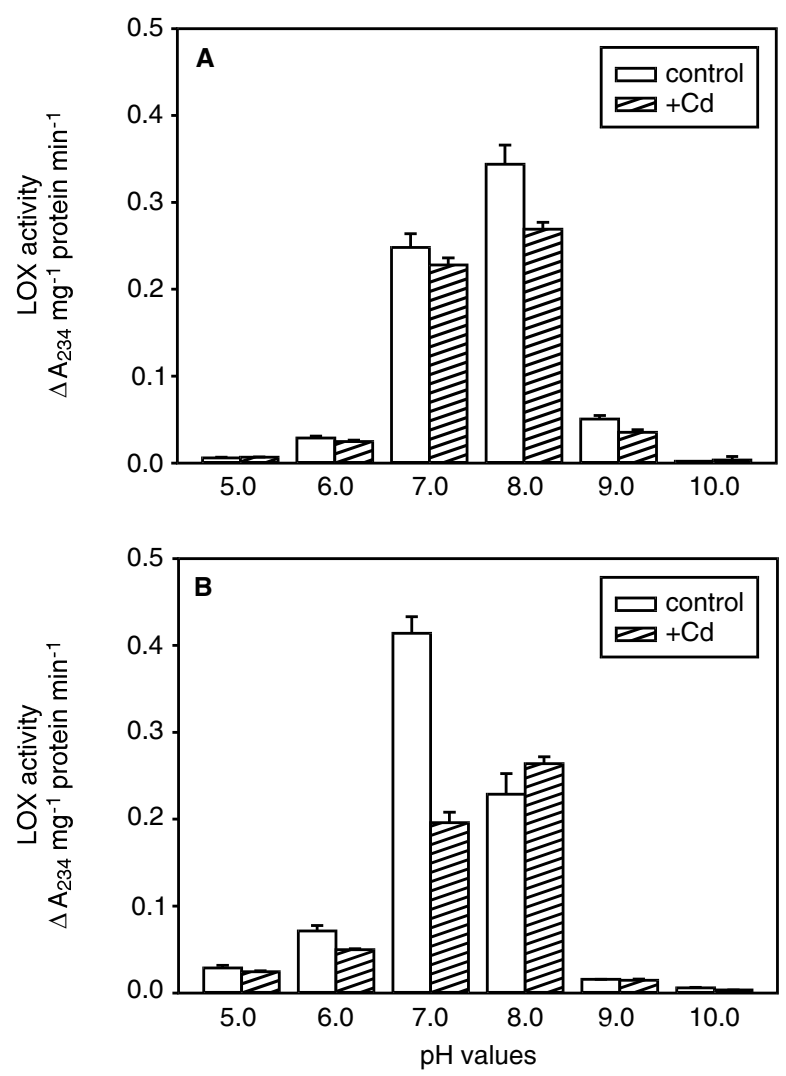

Fig 18. LOX activity in Cd-treated seedlings of Phaseolus coccineus in comparison with control growing for 2 (A) and 4 (B) days in the nutrient medium with of linoleic acid as substrate.

site of synthesis and digestion of fatty acids and phospholipids. LOX was also found in the cell wall area, at the tonoplast and inside partially differentiated plastids. After 2 days of plant growth in the nutrient solution there were no significant differences in LOX localization in the primary leaves of runner bean seedlings (Figs 7-11). Inside the plastids LOX was found at the lamellae. Additionally, LOX also appeared inside the mitochondria. Many plant LOXs are shown to be soluble, cytoplazmatic enzymes (Siedow 1991). They can be associated with membranes as a result of their charge modifications or they may be transferred via vesicles to target membranes (see Schaller and refs therein 2001).

The changes in the chloroplast structure under metal stress were shown earlier but during a longer plant exposition to heavy metals (Skórzyńska-Polit et al. 1995; Maksymiec et al. 1995). In the seedlings exposed to Cd for 2 days (Figs 12-16) cell parenchyma showed an atypical inner structure. In such changed cells less immunogold particles were observed in comparison with control. LOX was found in the cytoplasm, the cell wall area and in the vacuoles, but it was mostly observed as single gold particles. The vesicles and swollen lamellae of the chloroplast membranes were observed and the immunogold particles were only found in the plastid stroma. Two-day seedlings exposure to $\mathrm{Cd}$ resulted in the metal accumulation in developing leaves. After next 2 days the content of $\mathrm{Cd}$ in the primary leaves of Phaseolus coccineus slightly increased. Cadmium is easily uptaken by roots and transported to leaves where it is bound to phytochelatins (Tukendorf et al. 1997; Rauser 2001 and refs therein)

The protein content is reduced in Cd-treated plants (Romero-Purtas et al. 2002). Less immunogold particles in Cd-
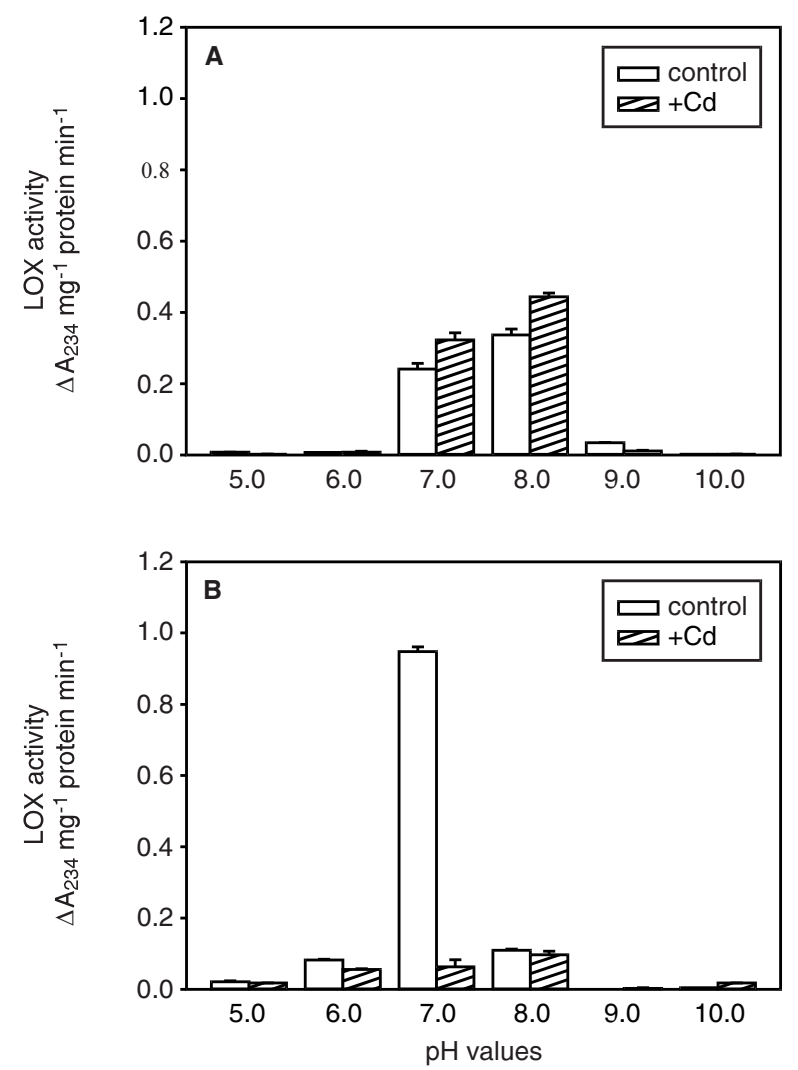

Fig 19. LOX activity in Cd-treated seedlings of Phaseolus coccineus in comparison with control growing for 2 (A) and 4 (B) days in the nutrient medium with of linolenic acid as substrate.

treated seedlings showed that the content of this enzyme protein was lower than in control. The phenomenon was related to lower LOX activity when linoleic acid was used as substrate but at the same time elevated LOX activity was measured when linolenic acid was used as substrate. It may be connected with direct and indirect effect of $\mathrm{Cd}$ on LOX activity. The activity of soluble LOX may be inhibited by $\mathrm{Cd}$ in a direct way, which was supported by its lower activity after 4 days of plant exposure to Cd (Fig. 18B). However, it cannot be excluded that the LOX activity may be modulated also in an indirect way via changes in the redox state of plants. Heavy metal stress resulted in changes of the level of cellular compounds like ascorbate, GSH, $\mathrm{H}_{2} \mathrm{O}_{2}$ (Gupta et al. 1999; Cuypers at al. 2000; Skórzyńska-Polit et al. 2003; Drążkiewicz et al. 2003). Because LOX requires one non-heme iron atom per molecule to its activity (Prigge et al. 1997) and the iron exists in the form $\mathrm{Fe}^{2+}$ or $\mathrm{Fe}^{3+}$ affecting the enzyme activity, thus it is possible that changes in the redox state of the plant cell may favour activation or inhibition of LOX activity.

Our hypothesis that in Phaseolus coccineus plants at least two isoforms of lipoxygenase are present, which are related to two optima $\mathrm{pH}$ for LOX activity, seems to be inadequate because lipoxygenase is localized almost in the same cell compartments in etiolated seedlings, control and Cd-treated plants growing under photoperiod. There are no any relationships between LOX activity and the kind of acid. Increased LOX activity at $\mathrm{pH}$ 7.0, when linolenic acid was used as substrate, may be correlated with the formation of lamellae in chloroplasts (Figs 7-11, 17B). In mature Phaseolus coccineus plants LOX activity has found mainly at $\mathrm{pH} 7.0$ and decreased with plant age, but LOX activity at $\mathrm{pH} 8.0$ 
was very low or disappeared (data not shown). Thus, LOX activity at $\mathrm{pH} 8.0$ seems to be related to the young stage of plant growth and/or to association of membranes.

In etiolated seedlings of Phaseolus coccineus LOX was mainly localized in the cytoplasm along ER elements, in vacuoles and inside chloroplasts. After exposure of control plant to 2 photoperiods LOX localization was very similar to that in etiolated seedlings, but in chloroplasts LOX was found at lamellae. In Cd-treated seedlings after their 2-dayexposure to the metal the LOX content was lower than in control. It was found mostly in vacuoles. Plastids were found with vesicles and swollen lamellae and LOX occurred only in the stroma of chloroplasts. Lower immunolabelling pointed to a lesser the enzyme protein content in Cd-treated plants. Changes in LOX activity may be related to direct or indirect influence of Cd (via the redox state of plant cell).

\section{ACKNOWLEDGEMENTS}

Polyclonal antibody against soybean LOX was produced by Agrisera, SE-911 21 Vännäs, Sweden, http://www.agrisera.se

\section{LITERATURE CITED}

BRADFORD M. 1976. A rapid and sensitive method for the quantitation of microgram quantities of protein utilizing the principle of protein-dye binding. Anal. Biochem. 72: 248-254.

CUYPERS A., VANGRONSVELD J., CLIJSTERS H. 2000. Biphasic effect of the copper on the ascorbate-glutathione pathway in the primary leaves of Phaseolus vulgaris seedlings during the early stages of metal assimilation. Physiol. Plant. 110: 512-517.

DRAŻKIEWICZ M., SKÓRZYŃSKA-POLIT E., KRUPA Z. 2003. Response of the ascorbate-glutathione cycle to excess cooper in Arabidopsis thaliana (L.). Plant Sci. 164: 195-202.

DROILLARD M.J., ROUET-MAYER M.A., BUREAU J.M., LAURIERE C. 1993. Membrane-associated and soluble lipoxygenase isoforms in tomato pericarp. Plant Physiol. 103: 1211-1219.

FEUSSNER I., KUHN H., WASTERNACK C. 2001. Lipoxygenase-dependent degradation of storge lipids. Trends Plant Sci. 6: 268-273.

FEUSSNER I., WASTERNACK C. 2002. The lipoxygenase pathway. Ann. Rev. Plant Biol. 53: 275-297.

FULLER A.M., WEICHERT H., FISCHER M., FEUSSNER I., GRIMES D.H. 2001. Activity of soybean lipoxygenase isoforms against esterified fatty acid indicates functional specificity. Arch. Biochem. Biophys. 6: 146-154.

GARDNER H.W. 1995. Biological roles and biochemistry of the lipoxygenase pathway. HortSci. 30: 197-205.

GUPTA M., CUYPERS A., VANGRONSVELD J., CLIJSTERS H. 1999. Copper affects the enzymes of thw ascorbate-glutathione cycle and its related metabolites in the roots of Phaseolus vulgaris. Physiol. Plant. 106: 262-267.

HILDEBRAND D.F., HAMILTON-KEMP T.R., LEGG C.S., BOOKJANS G. 1988. Plant lipoxygenases: occurrence, properties and possible functions. Curr. Topics Plant Biochem. Physiol. 7: 201-219

HOLTMAN W.L. VAN DUIJN G., SEDEE N.J.A., DOUMA A.C. 1996. Differential expression of lipoxygenase isoenzymes in embryos of germinating barley. Plant Physiol. 111: 569-576.

KATO T., OHTA H., TAKANA K., SHIBATA D. 1991. The appearance of new lipoxygenases in soybean cotyledons after germination and evidence for expression of a major new lipoxygenase gene. Plant Physiol. 98: 324-330.

KATO T., OHTA H., TANAKA K., SHIBATA D. 1992. Appearance of new lipoxygenases in soybean cotyledons after germination and evidence for expression of a major new lipoxygenase gene. Plant Physiol. 98: 324-330.

KOCH E., MEIER B.M., EIBEN H.-G., SLUSARENKO A. 1992. A lipoxygenase from leaves of tomato (Lycopersicon esculentum, Mill.) is induced in response to plant pathogenic Pseudomonas. Plant Physiol. 99: 571-576.

MACCARRONE M., VAN AARLE P.G.M., VELDINK G.A., VLIEGENTHARTY J.F.G. 1994. In vitro oxygenation of soybean biomembranes by lipoxygenase-2. Biochim. Biophys. Acta 1190: 164-169.

MAKSYMIEC W., BEDNARA J., BASZYŃSKI T. 1995. Responses of runner bean plants to excess copper as a function of plant growth stages: effects on morphology and structure of primary leaves and their chloroplast ultrastructure. Photosynthetica 31: 427-435.

MATSUI K., KAJIWARA T., HAYASHI K., HATANAKA A. 1988. Tissue specific heterogeneity of lipoxygenase in cucumber seedlings. Agr. Biol. Chem. 51: 3219-3221.

MELAN M.A., DONG X., ENDARS M.E., DAVIS K.R., AUSUBEL F.M., PETERMAN T.K. 1993. An Arabidopsis thaliana lipoxygenase gene can be induced by pathogens, abscisic acid, and methyl jasmonate. Plant Physiol. 101: 441-450.

MELAN M.A., ENRIQUEZ A.L.D., PETERMAN T.K. 1994. The LOX1 gene of Arabidopsis is temporary and spatially regulated in germinating seedlings. Plant Physiol. 105: 385-393.

PEEVER T.L., HIGGINS V.J. 1989. Electrolyte leakage, lipoxygenase, and lipid peroxidation induced in tomato leaf tissue by specific and nonspecific elicitors from Cladosporium fulvum. Plant Physiol. 90: 867-875.

PETERMAN T.K., SIEDOW J.N. 1985. Behaviour of lipoxygenase during establishment, senescence and rejuvenation of soybean cotyledons. Plant Physiol. 78: 690-695.

PRIGGE S.T., BOYINGTON J.C., FAIG M., DOCTOR K.S., GAFFENEY B.J., AMNEL L.M. 1997. Structure and mechanism of lipoxygenases. Biochimie 79: 629-636.

RAUSER W.E. 2001. The role of glutathione in plant reaction and adaptation to excess metals. In: Significance of glutathione in plant adaptation to the environment. Grill D., Tausz M., De Kok L.J. (eds). Kluwer Academic Publishers, Dordrecht, Boston, London, pp. 123-154.

RICKAUER M., FOURNIER J., POUENAT M., BERTHALON E., BOTTIN A., ESQUERRE-TUGAYE M. 1990. Early changes in ethylen synthesis and lipoxygenase activity during defense induction in tobacco cells. Plant Physiol. Biochem. 28: 647-653.

ROMERO-PUERTAS M.C., PALMA J.M., GOMEZ M., DEL RIO L.A., SANDALIO L.M. 2002. Cadmium causes the oxidative modification of proteins in pea plants. Plant Cell Environ. 25: 677-686.

SCHALLER F. 2001. Enzymes of the biosynthesis of octadecanoid-derived signalling molecules. J. Exp. Bot. 52: 11-23.

SCHMITT N.F, VAN MECHELEN J.R. 1997. Expression of lipoxygenase isoenzymes in developing barley grains. Plant Sci. 128: $141-150$

SIEDOW J.N. 1991. Plant lipoxygenases: structure and function. Ann. Rev. Plant Physiol. Mol. Biol. 42: 145-188.

SKÓRZYŃSKA-POLIT E., BEDNARA J., BASZYŃSKI T. 1995. Some aspects of runner bean plants response to cadmium at different stages of the primary leaf growth. Acta Soc. Bot. Pol. 4: 165-170.

SKÓRZYŃSKA-POLIT E., KRUPA Z. 2003. Activity of lipoxygenase in Arabidopsis thaliana - a preliminary study. Cell. Mol. Biol. Lett. 8: 279-284.

SKÓRZYŃSKA-POLIT E., DRĄ̇̇KIEWICZ M., KRUPA Z. 2003. The activity of the antioxidative system in cadmium-treated Arabidopsis thaliana. Biol. Plant. 47: 71-78. 
SOMASHEKARAIAH B.V., PADMAJA K., PRASAD A.R.K. 1992. Phytotoxicity of cadmium ions on germinationg seedllings of mung bean (Phaseolus vulgaris): Involvement of lipid peroxides in chlorophyll degradation. Physiol. Plant. 85: 85-89.

SPITELLER G. 2003. The relationshop between changes the cell wall, lipid peroxidation, proliferation, senescence and cell death. Physiol. Plant. 119: 5-18.

STELMACH B.A., MULLER A., HENNIG P., GEBHARDT S. SCHUBERT-ZSILAVECZ M., WEILER E.W. 2001. A novel class of oxylipins, sn-1-O-(12-oxophytodienoyl)-sn-2-O-(hexadecatrienoyl)-monogalctosyl diglyceride from Arabidopsis thaliana. J. Biol. Chem. 276: 12832-12838.

SUDHARSHAN E., SRINIVASULU S., APPU RAO A.G. 2000. $\mathrm{pH}$-induced domain interaction and conformational transitions of lipoxygenase-1. Biochim. Biophys. Acta 1480: 13-22.

TODD J.F., PALIYATH G., THMPSON J.E. 1990. Characteristic of a membrane-associated lipoxygenase in tomato fruit Plant Physiol. 94: 1225-1232.
TUKENDORF A., SKÓRZYŃSKA-POLIT E., BASZYŃSKI T. 1997. Homophytochelatin accumulation in Cd-treated runner bean plants is related to their growth stage. Plant Sci. 129: 21$-28$

VERNOOY-GERRITSEN M., LEUNISSEN J.L.M., VELDINK G.A., VLIEGENTHARTY J.F.G. 1984. Intracellular localization of lipoxygenase- 1 and -2 i germinating soybean seeds by indirect labelling with protein A-colloidal gold complexes. Plant Physiol. 76: 1070-1079.

VIANELLO A., BRAIDOT E., BASSI G., MACRI F. 1995. Lipoxygenase activity on the plasmalemma of sunflower protoplasts and its modulation. Biochim. Biophys. Acta 1255: 57-62 .

VICK B.A., ZIMMERMAN D.C. 1976. Lipoxygenase and hydroperoxide lyase in germinating watermelon seedlings. Plant Physiol. 57: 780-88. 